\title{
Influensa A/Sydney/5/97
}

\author{
Senga rister under meg idet eg vaknar og fortumla glytter kring i rommet. På veggane heng vovne tapet lause \\ over massiv steinmur. Bortpå veggen er det mura ein open eldstad i hoggen stein. Kva rom er dette? Har \\ huset vore borg eller kloster? Febersjukdomen kom i går då me susa sørover frå Paris til Angoulême i leige- \\ bil. I siderommet ligg svigerfar og rister, han klarer ikkje stå opp og maktar ikkje ete eller drikke.
}

Dei komande dagane vert svigerfar liggjande sløv, etter kvart med tung hoste. Mat og drikke vert tvinga i han. Svigermor nektar plent på at ho er sjuk. På ein handletur uvitar ho på fortauet.

Gamlefar frisknar noko, men er framleis sengeliggjande då eg i mangel på andre tiltak serverer han norsk tradisjonell helseeliksir med skei: brennevin frå dette sørfranske landskapet Cognac.

Me kjem alle levande heim.

\section{Legekontor og sjukeheim}

På legekontoret er arbeidsrutinane endra. Utanom dei vanlege allmennlegeoppgåvene, avtalebøker med fulle dagslister og vaktarbeid, sit eg i telefonen medan eg skriv ut sjukmeldingar. Sjukmeldingane kan ikkje vente, og pasientane er for sjuke til å kome på kontoret.

Etter arbeidstid ber det av garde til sjukeheimen. Me er inne i ein lokalepidemi eg verken før eller sidan har opplevd.

Medan eg med ektefelle og svigerforeldre var i Frankrike, har fleire av pasientane sjukna inn brått og alvorleg. Dagstøtt vert det meldt om nye febersjuke pasientar. Me to legane på kommunelegekontoret må rett som det er springe på sjukeheimen midt $\mathrm{i}$ dagen. Dessutan må me dit ettermiddag og kveld. Sjuke- og hjelpepleiarar har det annsamt. Det er mykje å gjere, det trengst ekstra mannskap. Kvar dag er det meldingar om nye sjuke. Nokre fell i koma. Gamle damer ligg i senga med høyrbar tung pust og ulydar frå brystet. Stetoskopet byr på ein kakofoni av framandlydar. Er det ødem, slim eller fortettingar? Me prøver med vanndrivande medisinar, antibiotika, drikke, til og med intravenøs væske, alt etter kva lungesymptom og funn, forstyrra medvit, blodtrykk eller testar kan gje hint om. Ingen tiltak tykkjest effektive. Ein del pasientar kjem seg ut or sjukdomen, trass i alle prognosar, men mange døyr. Ei kvinne sit ved matbordet om morgonen, innsjuknar på dagen og vert lagt $\mathrm{i}$ kista same kvelden.

Sykja rasar over sjukeheimen på tri veker og gjer to fredelege pleieavdelingar om til palliative storavdelingar. Personellet slit, men oppgåvene og det etiske imperativ manar til tapper innsats. Tankane går attende til 1918, til den uhyrlege spanskesykja.

Av dei 30 som er på heimen, vert 25 sjuke og 11 døyr. Eit par pasientar utanom var døyande då sykja råka. Ingen i bygda elles døyr.

Etter at epidemien er over, har me oppsummeringsmøte med alle tilsette på sjukeheimen. Erfaringar, tankar og kjensler vert delte. Nokre helsearbeidarar vart sjuke, nokre hadde sjuke familiemedlemmer. Det var imponerande korleis dei tok seg av einannan og gjorde arbeidet utan å verte motlause og nedbrotne. Sorga er der, men ikkje meiningsløyse eller klage. Det vert gitt og motteke ros for innsats.

Tanken på å leggje inn dei dødssjuke på sentralsjukehuset la me bort. Me trudde ikkje at overlevingsvonene var betre der. Nedsmittinga hjå oss var skræmande og kunne vorte overført til isolat og intensivavdelingar. Pasientar frå vår sjukeheim kunne paralysert deler av sentralsjukehuset.

\section{Media}

Eit par veker etter vart brått telefonen glødande. Eit helikopter med journalist og fotograf frå ei laussalsavis på Austlandet landa på plenen ved sjukeheimen. Andre kom sjøvegen. Den kommunale helsetenesta, representert av lege, pleiepersonal og administrasjon, streva med eit pågåande pressekorps. Jakta på syndebukkar var meir intens enn kunnskapshungeren.

Til all lukke hadde me laga tabell med tal på innsjukna og døde, handsamingsforsøk og vaksinasjonsstatus. Talspersonen vår kunne gjere greie for prosess og resultat. Avisartiklar synte sidan god innsikt. Det vart publisert ein notis i MSIS-rapporten (1).

Lokalepidemien gjekk føre seg i februar 1998. Aldersinstitusjonar i andre land melde sidan om likande lokalepidemiar på same tid (1). I mai 1997 vart ei ny influensastamme påvist i Sydney og fekk namnet influensa A/Sydney/5/97 (H3N2). Folkehelseinstituttet fekk melding om denne stammen for seint til å produsere ny vaksine for hausten 1997. Trippelvaksina som var tilrådd og produsert på våren vart brukt. Pasientar og helsepersonell hjå oss var vaksinerte etter vedtekne retningsliner.

\section{Lærdom og tolking}

Me legar opplevde oss meir som kollegaer med Bernard Rieux enn som representantar for den vestlege og potente medisinen. Den nemnde lege og humanist er helten i Pesten (2). I romanen registrerer og instruerer han, men har inga boteråd. Avmektig misser han reint motet. Han klarer fyrst ikkje finne samanheng i katastrofen (3), men ser at sjølve posisjonen som deltakande og observerande gjev meining. Denne allmennmedisinske grunntanken er også presentert i Plakaten (4). Jesuittpresten står i romanen for den teologiske fortolkinga. Han leitar etter meining i det meiningslause og tyr til Sodoma-forklaringa frå Det gamle testamentet (5). Det er ugudeleg livsførsel og dei mange syndene som har kveikt Guds vreide. Mennesket haustar som det har sådd. Botsgong gjev botevon.

I ei verd av urettvise, krig, ulukker og vald var dette ei lita katastrofe, ei spanskesykje i småskala. Dei som døydde, hadde hatt eit langt liv bak seg og var helsesvekka frå før. Opplevinga av å vere ein hjelpelaus tilskodar til intens infeksjonsinnsjukning og død justerte førestillinga om potens og effektivitet i moderne medisin.

\section{Aslak Bråtveit}

aslsigu@online.no

Aslak Bråtveit (f. 1951) er lege ved Finnøy legekontor, Finnøy.

Forfattaren har fylt ut ICMJE-skjemaet og oppgjev ingen interessekonfliktar.

Litteratur

1. Meldingssystem for smittsomme sykdommer. MSIS-rapport 1998; 19.

. Camus A. Pesten. Oslo: Aschehoug, 2000

3. Antonowski A. Health, stress and coping. San Francisco, CA: Jossey-Bass, 1979

4. Sju teser for allmennmedisin. Plakaten. Tese 2 Gjør det viktigste. Oslo: NSAM, 2001

5. Bibelen. 1. Mos 19.

Motteke 3.6. 2015, første revisjon sendt inn 6.10. 2015, godkjent 21.10. 2015. Redaktør: Sigurd Høye. 